\title{
Revisitando os altares domésticos: os usos dos espaços domésticos como parte da experiência religiosa
}

\author{
Carlos Eduardo Machado*
}

Resumo: 0 presente artigo busca compreender a dinâmica que envolve a noção de espaço e a ideia de sagrado com base no posicionamento das imagens religiosas em residências de famílias católicas. Baseando-se na observação das residências, de fotografias e entrevistas, o trabalho propõe a compreensão dos altares religiosos dentro de um contexto religioso plural, que se expressa no consumo de bens sagrados, bem como na disposição espacial das imagens no contexto doméstico, sugerindo distintas experiências religiosas no contexto familiar.

Palavras-chave: altares, imagens, casa.

\section{Introdução}

"Sua família possui imagens de santos em casa?". Esta foi uma das questões que compunham o questionário que aplicamos na primeira etapa de nossa pesquisa1. Iniciada no começo de 2011, nossa proposta é a de compreender as reconfigurações do campo religioso brasileiro com base nos casos que apresentam uma pluralidade religiosa intrafamiliar.

No decorrer da pesquisa, foi possível identificar diversas residências² que possuíam membros de diferentes religiões, sendo mais notável a presença de católicos e evangélicos na mesma residência. Começamos com as imagens de santos que os católicos possuem para compreendermos como são desenvolvidas as relações cotidianas entre os membros que compõem a residência, tendo em vista que a iconografia se apresenta como parte constituinte da identidade católica e a iconoclastia como elemento identitário do protestantismo e de suas ramificações.

\footnotetext{
* Graduando em Ciências Sociais - UNESP.

${ }^{1} \mathrm{O}$ questionário foi composto pelas seguintes perguntas: Possui religião? Qual religião? Frequenta a igreja? Quantas pessoas moram na casa? Quais as idades das pessoas que moram na casa? Todas as pessoas da casa são da mesma religião? Tem algum santo de devoção? Sua família possui imagens de santo em casa?

2 Neste trabalho, optamos por expor os dados das residências católicas que possuíam imagens de santos, mesmo perpassando pelas residências que apresentavam certa pluralidade religiosa. A seleção dos dados passou por um critério aleatório, percorrendo o maior número de residências possíveis e entrevistando moradores disponíveis no momento. No caso das fotografias apresentadas, foram residências onde, após as entrevistas, pudemos retornar e fotografar, desse modo, os dados apresentados foram selecionados valendo-se das eventualidades que o campo apresentou.
} 
Para este artigo nos concentramos em um dos aspectos que compõem nosso trabalho: as imagens de santos presentes nas residências católicas. Embora nosso foco principal seja a pluralidade religiosa intrafamiliar, também atentamos para as famílias que se declaram totalmente evangélicas e as totalmente católicas, podendo, assim, conhecer o contexto no qual se inserem as famílias com pluralidade religiosa.

Este artigo faz parte de um projeto maior ainda em desenvolvimento que se propõe a refletir sobre "qual catolicismo é este de hoje?”, "quais são suas formas?", "como os religiosos experimentam e constroem suas visões de mundo com base nele diante de outros universos religiosos?". Indagações estas, como as de Pierre Sanchis (1995) e Carlos Steil (2001), indicam que a dinâmica pela qual passa o campo das religiões no Brasil é resultado da própria modernidade, derivando pluralismos, trânsitos e múltiplos sentidos, sendo necessários dados empíricos para que possamos diagnosticar suas constantes transformações.

Para isso, oferecemos alguns tópicos desenvolvidos em nossa pesquisa de campo, tomando uma fração do costume católico em possuir imagens de santos para devoção, analisando por fotografias o posicionamento das imagens de santos (compreendendo imagens de santo como quadros, crucifixos, imagens de gesso, plástico, madeira, entre outros objetos considerados pelos devotos como sagrados) presentes em algumas casas.

Interessa-nos nesta pesquisa o espaço privado da casa, por adquirir no imaginário da sociedade brasileira um locus privilegiado,

\begin{abstract}
marcada pela familiaridade e hospitalidade perpétuas que tipificam aquilo que chamamos de "amor", "carinho" e "consideração". Do mesmo modo, "estar em casa" ou sentir-se em casa fala de situações onde as relações são harmoniosas e as disputas devem ser evitadas. Não posso transformar a casa na rua e nem a rua na casa impunemente. Há regras para isso (DAMATTA, 1985, p. 46).
\end{abstract}

Entendendo a relevância dos estudos sobre a relação santo-devoto e também as relações que são estabelecidas pelas imagens de santos, buscamos seguir a observação da antropóloga Renata Menezes (2005, p. 27), que sugere para esse empreendimento indagarmos sobre o sentido que determinadas práticas devocio- 
nais, geralmente classificadas de "tradicionais", isto é, tidas como representativas de um catolicismo "popular tradicional", assumem nos dias de hoje.

Nesse sentido, a questão atual que se levanta sobre a religião é: do que somos contemporâneos e quais são "as tonalidades da devoção em nossa época?" (GEERTZ, 2001, p.152). Desse modo, lançamos mão de autores clássicos e contemporâneos que possibilitam ampliar o debate e produzir um conhecimento sobre as ações dos agentes sociais e de suas apropriações dos espaços domésticos e nos usos das imagens religiosas em suas práticas diárias.

\section{Contextualizando: o locus da pesquisa}

Nossa pesquisa desenvolve-se na cidade de Borá, localizada no centro-oeste do estado de São Paulo, cerca de $522 \mathrm{~km}$ da capital. Borá foi reconhecida como o município brasileiro com a menor população do país pelo IBGE em 2010, contendo 805 habitantes. Até o ano de 1964 pertencia ao distrito da cidade de Paraguaçu Paulista, elevando-se no mesmo ano a município.

Suas ruas estreitas enlaçam-se e comportam às margens casas de alvenaria e madeira, direcionando qualquer visitante ao centro da cidade onde está a única igreja católica da cidade, a igreja de Santo Antônio de Borá. Situada na praça central, a igreja é cercada por residências, um pequeno comércio com uma mercearia, uma farmácia, um açougue, órgãos municipais como o Paço Municipal, uma delegacia, um centro comunitário e um cartório. Aos derredores, em ruas acima da praça central, é possível encontrar outro mercado, o "Mercado do Povo", um pequeno restaurante, uma lotérica, três bares, um cemitério, um velório, uma agência dos correios e um posto de gasolina.

No que tange à religiosidade dos boraenses, encontramos quatro igrejas evangélicas: duas Assembleias de Deus, uma Igreja do Evangelho Quadrangular e uma Igreja Congregação Cristã. Segundo uma informante, existe também uma casa onde se celebram cultos evangélicos. As igrejas evangélicas mantêm certa distância espacial entre si, distribuem-se a partir da Igreja de Santo Antônio, estando dispostas em direções opostas. 
Borá tem sua história marcada pela colonização de famílias portuguesas e italianas que, por volta de 1918, habitaram a região, edificando a Capela de Santo Antônio de Borá (hoje igreja) e solidificando aos poucos a vila até se tornar município. Com isso, a tradição católica de origem ibérica, principalmente, mantém traços característicos muito profundos nos descendentes que ali permanecem e em outros que se achegam e fixam residência.

Outro fator relevante para tomarmos a cidade de Borá como campo de pesquisa decorre de inúmeras transformações que o pequeno município vem passando nos últimos dez anos. No início de 2000, uma usina de cana-de-açúcar instalouse na região, reconfigurando toda a estrutura econômica da cidade, que até então tinha a maior parte de seus habitantes, cerca de 70\%, como trabalhadores empregados pela prefeitura da cidade.

A usina também promove um fluxo contínuo de migrantes que se deslocam de outros estados - principalmente das regiões norte e nordeste - para trabalharem na temporada de colheita da cana. Esses trabalhadores não fixam residência, porém, a movimentação diária em Borá dá-se principalmente por eles, que transitam pela cidade. É possível compreender como esse fator alterou a vida dos boraenses pelo relato de uma senhora, moradora antiga da cidade, descendente de portugueses que colonizaram a região, que nos disse "não dá mais pra saber quem anda pelas ruas, antes a gente conhecia todo mundo".

A escolha de Borá deu-se pela possibilidade de construir um campo de pesquisa relativamente reduzido, dentro de um espaço bem definido em termos de referenciais geográficos. No entanto, Borá não é "uma ilha", não está "parada no tempo", visto que está inserida no contexto mais amplo do sudoeste paulista, assim, julgamos que é um caso empírico com muito potencial.

Diante disso, partimos da firme constatação de que não se trata de buscar em Borá o "exótico", ou romancear numa ideia bucólica a fim de despertar interesses ou a atenção flutuante sobre o trabalho. Pelo contrário, como aponta Morales (2002, p. 10) sobre a prática etnográfica, trata-se de apontar para um modo de vida e de percepção singulares e tão legitimamente humanos quanto qualquer outro. 


\title{
A escolha teórica e metodológica para a análise
}

Optamos seguir para a análise autores da antropologia e sociologia que nos permitem pensar, por um ponto microscópico, as configurações atuais do catolicismo no Brasil. Também nos valemos da contribuição de historiadores para compreender as continuidades e descontinuidades desse costume e, porque não, as formas originais que as novas práticas culturais reelaboradas podem estar gerando (MENEZES, 2004, p. 25-26).

Assim, buscamos em Clifford Geertz (1989) a ideia de motivações e de disposições, para compreender as ações dos agentes na opção por determinados locais para depositar as imagens de santos, entendendo suas motivações e disposições como inclinações a algo. Desse modo, coloca Geertz sua definição como:

\begin{abstract}
No que nos concerne, entretanto, a diferença mais importante entre disposições e motivações talvez resida no fato de que as motivações são "tornadas significativas" no que se refere aos fins para os quais são concebidas e conduzidas, enquanto as disposições são "tornadas significativas" no que diz respeito às condições a partir das quais se concebe que eles surjam. Interpretamos os motivos em termos de sua consumação, mais interpretamos as disposições em termos de suas fontes (GEERTZ, 1989, p. 72).
\end{abstract}

Sendo as motivações significativas na objetivação da ação, isto é, para a finalidade a qual é dirigida, as disposições têm seu significado valendo-se das condições em que o contexto as torna possíveis para que sejam objetivadas. É possível entender a dicotomia de Geertz como um cruzamento ambivalente de ações, como se o religioso fosse motivado pela religião para se guiar no mundo ao mesmo tempo em que tem suas disposições religiosas fornecidas pelo contexto que o circunscreve. Esse contexto pode ser o de sua casa, da roda de amigos, dos contatos sociais em geral, da igreja ou comunidade que frequenta etc.

No contexto selecionado para este estudo, as imagens religiosas e suas alocações espaciais dentro da casa, as motivações e disposições que buscamos analisar são os meios diferenciados, criativos, singulares, que os agentes encontram para experimentar sua identidade religiosa no ambiente doméstico. Por isso, buscamos em Michel De Certeau (2011) o conceito de estratégias e táticas desenvolvidas no cotidiano. 
Certeau compreende as estratégias e táticas cotidianas como uma gama de ações combinatórias operacionalizadas pelos agentes sociais, rompendo com a característica de dominados ou meros consumidores, mas como inventores de formas não evidenciadas que permeiam o cotidiano, dando-lhes o status de verdadeiros produtores de alteridade (CERTEAU, 2011, p. 37-38). São, portanto, "essas as maneiras de fazer que constituem as mil práticas pelas quais os agentes se reapropriam do espaço organizado pelas técnicas da produção sociocultural" (idem, p. 41), que se tornam nosso objeto de estudo.

Assim define Certeau seu conceito de estratégia:

Chamo de estratégia o cálculo (ou a manipulação) das relações de forças que se torna possível a partir do momento em que um sujeito de querer e poder (uma empresa, um exército, uma cidade, uma instituição científica) pode ser isolado. A estratégia postula um lugar suscetível de ser circunscrito como algo próprio e ser a base de onde se podem gerir as relações com uma exterioridade de alvos ou ameaças (os clientes ou os concorrentes, os inimigos, etc.) (CERTEAU, 2011, p. 93).

\section{Por táticas define:}

[...] chamo de tática a ação calculada que é determinada pela ausência de um próprio. Então nenhuma delimitação de fora lhe fornece a condição de autonomia. A tática não tem por lugar senão o do outro. E por isso deve jogar com o terreno que lhe é imposto tal como organiza a lei de uma força estranha. Não tem meios para se manter em si mesma, à distância, numa posição recuada, de previsão e de convocação própria: a tática é o movimento "dentro do campo de visão do inimigo" [...] e no espaço por ele controlado. [...] Ela opera golpe por golpe, lance por lance. Aproveita as "ocasiões" e delas depende, sem base para estocar benefícios, aumentar a produtividade e prever saídas. O que ela ganha não se conserva. Este não lugar lhe permite sem dúvida mobilidade, mas numa docilidade aos azares do tempo, para captar voo as possibilidades oferecidas por um instante. Tem que utilizar, vigilante, as falhas que as conjunturas particulares vão abrindo na vigilância do poder proprietário. Aí vai caçar. Cria ali surpresas. Consegue estar onde ninguém espera. É astúcia (idem, p. 94-95).

Por isso, para encontrar essas estratégias e táticas que surgem das motivações e disposições religiosas no cotidiano e traçar interpretações a seu respeito, valeremo-nos de dados quantitativos fornecidos pela primeira etapa de nossa pesquisa, como também, de breves depoimentos, observação e fotografias do interior das residências visitadas na cidade de Borá. Nossa discussão alternará entre a exposição das fotografias e sua análise, porém, antes é necessário resgatarmos ideias cristalizadas sobre os altares domésticos, para em seguida, propormos uma desnaturalização das ideias sobre a prática da devoção e dos usos dos objetos religiosos. 


\section{Altares religiosos domésticos: algumas modalidades de usos na história brasileira}

Por certo, a religião sempre foi de grande importância na vida pública como na vida privada dos brasileiros, como coloca Montes (1998, p. 69). Nesse bojo religioso no qual o país se constituiu, o catolicismo figurou de modo singular, foi nele que o projeto da nação encontrou "um conjunto de valores, crenças e práticas institucionalmente organizadas e incontrastadamente hegemônicas que por quatro séculos definiram de modo coerente os limites e as interseções entre a vida pública e a vida privada" (idem, p. 73).

Como argumenta Hoornaert (1994, p. 13), a cristianização de toda a América Latina teve um caráter quase que exclusivamente político, isto é, uma construção pública de imaginários, valores e de ações coercitivas sobre os povos colonizados. Todavia, como pondera o autor, o homem não é somente um "animal político", sua vida é também procura de sentido, de felicidade e de realização.

Sendo assim, essa busca de sentido naturalmente humano não se ajustou completamente ao catolicismo oficial trazido pelo europeu colonizador ${ }^{3}$, derivando disso um hibridismo religioso, que foi capaz de produzir no passado brasileiro e na história do catolicismo histórias diversas e fragmentadas na experiência de seus adeptos (HOONAERT, 1994, p. 152).

Atentando, portanto, para as características particulares que essa história ou essas histórias - pôs a disposição para que o catolicismo fosse sistematizado pela população, é possível supor que nesse contexto se organizaram de tal modo os preceitos religiosos cristãos com as culturas estranhas a estes, que, mesmo em meio a toda barbárie contra indígenas e africanos, o catolicismo foi ganhando cor e sentido próprios, unindo elementos aparentemente distintos e produzindo interpretações outras do que seria religião e, principalmente, do que seria a prática religiosa (SANCHIS, 2008, p. 79).

Aqui, cabe trazer à discussão o pensamento de Alphonse Dupront, que aponta:

\footnotetext{
3 A clara constatação da afirmativa são os "santos" não canonizados cultuados no Brasil. Dentre eles, destacamos talvez o mais conhecido, padre Cícero Romão Batista, o qual fora tão bem discutido por diversos pesquisadores como no estudo realizado por Antônio Mendes da Costa Braga (2008) e na discussão ensejada por Pierre Sanchis (2007).
} 
[...] por um lado, o que se denomina de "catolicismo" não se limita, na honestidade das palavras, à religião católica como tal. Como o sufixo traduz numa penumbra propícia e fecunda, é preciso entender no conteúdo existencial de "catolicismo", tanto um sistema de pensamento como uma atitude diante do mundo e da vida (DUPRONT, 1995, p. $10)$.

Dupront (1995, p. 10-11) também ressalta que a religião católica se diferencia da prática exercida pelo fiel, isto é, do conteúdo existencial do catolicismo, e que ambas encaram o desafio moderno de se equilibrarem na experiência com a alteridade (idem, p. 27). Assim, o catolicismo brasileiro ganha suas particularidades cabíveis para a análise, tal como nos diversos fenômenos religiosos das romarias ao Santuário de Bom Jesus da Lapa estudado por Steil (1996, p. 77), em que os religiosos criam um sagrado alternativo, independente, manifesto fora do espaço convencionado como tradicional para sua realização. E, também, suas manifestações oficiais como no Convento Franciscano estudado por Menezes (2004), onde, em meio ao caos da metrópole carioca, realiza-se em dias semanais e horários pouco habituais o culto a Santo Antônio.

Nessa linha, compreendemos que a singularidade e abrangência que o catolicismo alcançou na vida privada se manifestaram desde o período colonial de modo proeminente em nossa sociedade. Como nas estruturas das casas-grandes, nas quais o contato com a presença do sagrado na propriedade doméstica era inerente a elas. De acordo com Freyre (1954), foi na capela de engenho, anexa ou isolada da casa de moradia ${ }^{4}$, que o catolicismo alicerçou suas primeiras bases nas famílias abastadas do período colonial.

Mas a igreja que age na formação brasileira, articulando-a, não é a catedral com o seu bispo a que se vão queixar os desenganados da justiça secular: nem a igreja isolada e só, ou de mosteiro ou abadia, onde se vão acoitar criminosos e prover-se de pão e restos de comidas mendigos e desamparados. É a capela de engenho (FREYRE, 1954, p. 363-364).

Contudo, não somente as famílias de engenhos possuíam uma estreita relação com o sagrado, mas as classes populares também se valeram das estratégias e das táticas possíveis para veicular sua experiência com o sagrado. Como seu acesso

\footnotetext{
4 Mais informações podem ser consultadas na dissertação de Manoel Humberto Silva Santos (2006), que pesquisou, baseado no inventário dos bens imóveis do Recôncavo, os diversos tipos de espaços destinados à oração existentes em sedes de fazendas e engenhos.
} 
à capela era subordinada à presença das famílias patriarcais - que muitas vezes preferiam evitar o contato de suas filhas com a plebe (SANTOS, 2006) -, trouxeram para dentro de suas casas as imagens religiosas, como nos mostra Lopes, citando Hoornaert:

As apropriações das imagens religiosas pelos segmentos populares, com vistas à produção do consumo, não são um fato recente na cultura católica brasileira. Desde a Colônia é possível perceber, como afirma Hoonaert [...], que "também os oprimidos exprimiam sua experiência em imagens, ou, mais sutilmente, deram um significado próprio às imagens que os opressores trouxeram consigo" (LOPES, 2010, p. 89).

Russo (2010) reforça a ideia de que, no Novo Mundo, o catolicismo fora absorvido de um modo muito particular, e, no que tange aos usos da iconografia religiosa, a autora explica que:

Neste corpus, é possível encontrar um diversificado repertório de imagens com temas correspondentes à iconografia católica, evidenciando a política da evangelização portuguesa que causou uma relevante repercussão no Novo Mundo [...]. Vislumbra-se a Virgem, e o próprio Cristo, como as personagens sagradas mais invocadas, a suscitar, por certo, interpretações várias, geradas pelo contato dos fiéis com as imagens devotas, estimulando, por certo, a criação de laços de identidade e confiança, e ainda, rompendo barreiras e estimulando o diálogo em primeira pessoa com a divindade (Russo, 2010, p. 397-398).

Com essa apropriação e aproximação dos objetos sagrados pelos religiosos - tanto dentro dos engenhos quanto os usos que as classes populares produziam -, instalou-se fortemente no país um tipo singular de catolicismo, o catolicismo santorial que, segundo Teixeira (2005), representou um tipo de devoção que propiciou a relação íntima dos devotos com os santos.

O catolicismo santorial, para usar uma expressão de Cândido Procópio Camargo, é uma das formas mais tradicionais de catolicismo presentes no Brasil desde o período da colonização. Tem como característica central o culto aos santos. Foi esse culto que marcou a peculiar dinâmica religiosa brasileira, de caráter predominantemente leigo, seja nas confrarias e irmandades, seja nos oratórios, capelas de beira de estrada e santuários. 0 catolicismo brasileiro foi durante muito tempo um catolicismo de "muita reza e pouca missa, muito santo e pouco padre". Os santos sempre ocuparam um lugar de destaque na vida do povo, manifestando a presença de um "poder" especial e sobre-humano, que penetra nos diversos espaços de vida e favorece, numa estreita aproximação e familiaridade com seus devotos, a proteção diante das incertezas da vida (TEIXEIRA, 2005, p. 17). 
Esse tipo de devoção que privilegia o culto aos santos no período colonial foi uma marca registrada da religiosidade nas casas. Era, segundo Mott (1997), desde o despertar que o cristão se via rodeado de lembranças do Reino dos Céus ${ }^{5}$. Em diversos lugares como

[...] na parede contígua à cama, havia sempre algum símbolo visível da fé cristã: um quadrinho ou caixilho com gravura do santo anjo da guarda ou do santo onomástico; uma pequena concha com água benta; o rosário dependurado na própria cabeceira da cama (Mотт, 1997, p. 164).

O mesmo autor oferece-nos um panorama do hábito das famílias mais abastadas com relação à proximidade que conferiam aos santos:

As famílias um pouco mais abastadas possuíam um quarto especial, o quarto dos santos. Seu tamanho variava, e às vezes era apenas uma "nesga de espaço debaixo de escada que conduzia ao sótão ou aposento para custódia de imagens". Não eram poucos os que conservavam as imagens em seus próprios aposentos. "Todas as alegrias e tristezas eram relatadas entre preces aos bentos simulacros bem guardados em um nicho de madeira forte, torneado e envernizado, com três faces de vidro" (idem, p. 166).

Essas informações permitem-nos questionar se o catolicismo santorial, tal como descrito acima, continua mantendo seus aspectos tradicionais, e como está, contemporaneamente, desenvolvendo-se o uso das imagens nas residências dos devotos.

Sem ter a pretensão de revisar uma extensa bibliografia sobre a prática católica do uso de imagens, nosso propósito é salientar abordagens da clássica historiografia brasileira e produções recentes sobre a temática, visando concentrar a discussão num determinado contexto: o das famílias católicas e suas práticas de posicionamento das imagens dos santos. A discussão não pretende deixar de lado a complexidade da relação existente entre vizinhos, parentes, chegados, que colocam em questão o pertencimento religioso e suas distintas identidades em um locus como a cidade de Borá.

\footnotetext{
${ }^{5}$ A título ilustrativo vale citar o filme brasileiro Lavoura Arcaica, baseado na obra de Raduan Nassar, que retrata resquícios da vida colonial no sul do Brasil.
} 


\section{O lugar dos santos: uma análise com base na cidade de Borá}

A tabela a seguir indica alguns dados preliminares sobre a pesquisa de campo realizada:

\begin{tabular}{|l|c|}
\hline \multicolumn{1}{|c|}{ TOTAL DE RESIDÊNCIAS } & $\mathbf{2 0 0}$ \\
\hline Residências visitadas & 52 \\
\hline $\begin{array}{l}\text { Residências que se declaram totalmente católi- } \\
\text { cas }\end{array}$ & 33 \\
\hline $\begin{array}{l}\text { Residências que se declaram totalmente evan- } \\
\text { gélicas }\end{array}$ & 3 \\
\hline $\begin{array}{l}\text { Residências com pluralidade religiosa intrafa- } \\
\text { miliar }\end{array}$ & 12 \\
\hline Residências sem religião & 4 \\
\hline $\begin{array}{l}\text { Residências que possuem imagens de santos } \\
\text { católicos em casa }\end{array}$ & 31 \\
\hline
\end{tabular}

A cidade de Borá possui atualmente 200 residências. Dentre as 52 residências visitadas, 33 declararam-se totalmente católicas, 3 residências declararam-se totalmente evangélicas, 12 possuem uma pluralidade religiosa intrafamiliar, que versava entre católicos e espíritas e/ou evangélicos e católicos e, por fim, apenas 4 disseram não possuir nenhuma religião - embora já tivessem tido experiências religiosas, no momento preferiram se declarar sem religião.

As entrevistas foram realizadas aos sábados, pois seria um dia privilegiado para encontrarmos todos ou quase todos os membros nas residências, visto que muitos membros das famílias trabalham durante os dias úteis semanais. No momento da abordagem estavam presentes no mínimo dois membros da família 6 . Embora não exigíssemos a presença de mais de um membro, filhos, pais, irmãos e demais pessoas que estavam presentes se aproximavam e auxiliavam o entrevistado a responder o questionário.

As fotografias que iremos expor são das residências que se declararam totalmente católicas, deixando-se para uma próxima oportunidade a análise das re-

\footnotetext{
${ }^{6}$ Cabe aqui situar o leitor de que a noção de família com a qual trabalhamos não se restringe simplesmente aos laços consanguíneos, mas a outros tipos de estruturas familiares que agregam laços não consanguíneos e que compartilham o mesmo teto. Optamos por essa classificação fundamentados no trabalho de Claudia Fonseca (2004), que nos leva a compreender lógicas distintas de "família", sendo agregada à estrutura amigos, chegados, entre outros. É possível, assim, inserir na noção de família aqueles que compõem o cotidiano dos moradores em suas diversas ações diárias no espaço doméstico.
} 
sidências com pluralidade religiosa intrafamiliar que possuem imagens de santos. Posto isto, as imagens que encontramos - tanto nas selecionadas para a análise quanto outras que compõem o material etnográfico - estão dispostas em salas, quartos, cozinhas, umbrais de portas, cantos específicos da casa, sobre estantes, racks, geladeiras, mesas, armários, no chão, penduradas em paredes, ocupando espaços não tradicionais, ou, convenientes à ideia de um lugar estritamente reservado para a imagem de um "santo".

Selecionamos 11 fotografias de 8 residências diferentes. Iniciemos, então, por um lugar reservado da casa: em vez de iniciarmos pela porta de entrada, começaremos pelo quarto, lugar íntimo, de repouso, que revela muitos dos nossos quadros de emoções.

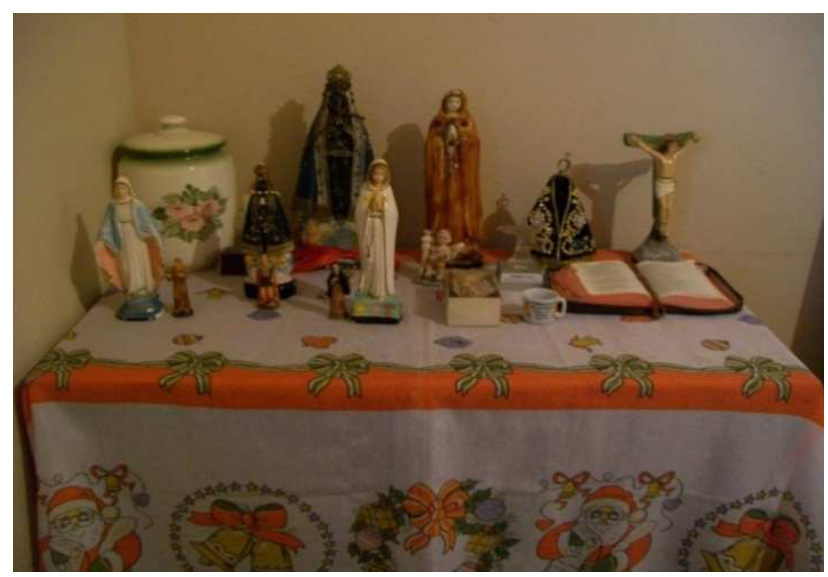

Figura 1

Na figura 1 é possível identificar algumas imagens conhecidas dos devotos brasileiros como Nossa Senhora Aparecida, Jesus Cristo Crucificado, Virgem Maria e outros santos. Não somente os santos católicos figuram nesse pequeno altar, mas no centro podemos ver a imagem de um pequeno anjinho. Também miniaturas de outros santos, uma Bíblia aberta e uma pequena louça com mensagem bíblica, todos sobre uma toalha de enfeites natalinos postos sobre uma pequena mesa no canto do quarto.

Que apreensão podemos fazer disso? Dentre as residências visitadas, essa foi a única em que a informante, uma mulher casada, católica, dona da residência, informou-nos "eu tenho meu altarzinho no quarto". Em outras residências, informaram-nos que também tinham no quarto, mas não exclusivamente no quarto, como neste caso, mas espalhadas pela casa. 
Outro aspecto relevante é que, no momento da entrevista, após a solicitação para fotografar as imagens que a dona da casa possuía, ela permitiu que fossem fotografadas desde que uma de suas filhas o fizesse. Isso indicou para o pesquisador naquele momento que o quarto e o altar só poderiam ser acessados por pessoas íntimas da casa, um estranho não poderia adentrar, haveria ali um estabelecimento de fronteiras entre os que são da casa e aqueles que são da rua (DAMATTA, 1985, p. 21).

É conveniente pensar o caso com base na reflexão de Norbert Elias (2011), o modo que nossa sociogênese foi configurada por um processo contínuo de adaptação e adequação de valores, estabelecendo um modo específico de perceber e sentir o mundo. No caso do quarto é compreensível por tratar-se de um local de mínima penetração social, como o máximo divisor de águas entre o público e o privado, concentrando nele todo um resguardo pessoal (ELIAS, 2011, p. 157).

O altar no quarto representaria, então, o local mais sagrado da casa - e por que não do mundo? - para o devoto, uma vez que ali estariam aglomerados sentimentos de proteção, de conforto, de tranquilidade. No entanto, essa sacralidade do ambiente não seria rompida pela profanação do sexo, permitindo que no quarto fosse possível a coexistência de uma dada noção de sagrado e de profano. Essa interpretação sugere, na ação do devoto, uma elaborada gama de combinações que conferem significados distintos às ações no quarto. Rezar em frente ao altar doméstico e ter ao seu redor a cama, lugar por excelência do sexo, não é pensado como antagonismo, realizando, na verdade, uma necessidade de ter a aprovação divina dos seus atos mais íntimos em todos os momentos.
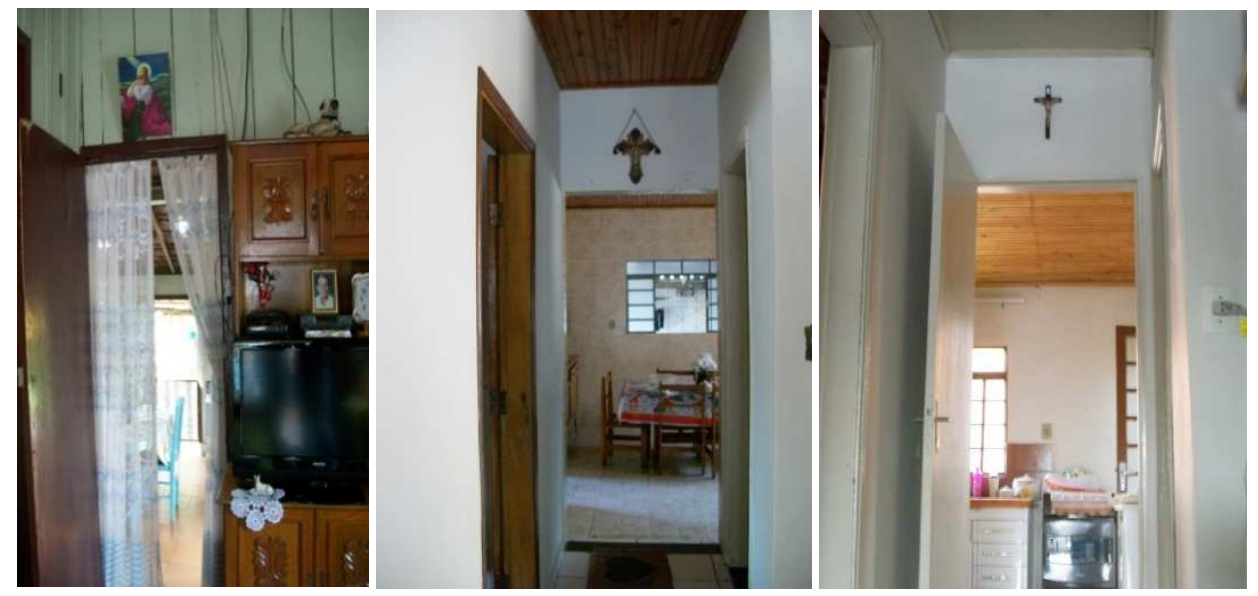

Figura 2 
Na figura 2 vemos umbrais de portas. Na primeira imagem, um quadro com a representação de Jesus orando; na segunda, um crucifixo de madeira estilizado; na terceira e última, outro crucifixo de madeira simples. Nas três fotografias é notório que o local da casa escolhido são corredores que levam à cozinha das residências. Após a porta encontramos cadeiras, mesas, armários típicos de cozinha e outros entornos que conotam o espaço.

Tomando o pensamento de Baudrillard (1973) como referência, é possível compreender o uso desses espaços com o sentido de função, em que cores, formas, materiais, objetos, arranjos e espaços são utilizados para exercer uma determinada ordenação funcional de sua disposição, encerrando nelas as características da modernidade.

\footnotetext{
Derivado de "função", ele sugere que o objeto se realiza na sua exata relação com o mundo real e com as necessidades do homem. Efetivamente, resulta das análises precedentes que "funcional" não qualifica de modo algum aquilo que se adapta a um fim, mas aquilo que se adapta a uma ordem ou a um sistema: a funcionalidade é a faculdade de se integrar em um conjunto. Para o objeto, é a possibilidade de ultrapassar precisamente sua "função" para uma função segunda, de se tornar elemento de jogo, de combinação, de cálculo, em um sistema universal de signos (BAUDRILLARD, 1973, p. 6970; grifos nossos).
}

Dentre as três fotografias apresentadas, somente na segunda indagamos o motivo de se ter um crucifixo no umbral da porta. Nossa informante, uma mulher casada, explicou-nos com entusiasmo "que era para proteger a casa". Embora nossa proposta aqui não esteja concentrada no discurso dos informantes, mas sim nas noções de espaço e nas relações que estabelecem com a ideia de sagrado, essa fala ajuda-nos a tratar de modo mais claro essa explicação.

Tal como Certeau na sua definição de estratégia, Baudrillard utiliza a palavra cálculo, direcionando para aquilo que Lopes (2003) aponta nas análises sobre as imagens religiosas e os seus usos: compreender no caso brasileiro como um campo imagético plural, onde os agentes sociais negociam e desenvolvem arranjos diversos com base em suas religiosidades.

Assim, podemos sugerir que o posicionamento das imagens sobre os umbrais comporta mais do que a ideia de proteção, vincula também a mensagem a qualquer pessoa que adentre o recinto. É uma mensagem que indica a religiosidade presente na casa, buscando impor de modo dissimulado, como argumenta Bourdi- 
eu (1998, p. 33-34), uma representação da crença praticada pelo devoto, ou seja, uma representação dos padrões de comportamento aceitáveis e dos não aceitáveis naquele determinado espaço doméstico.

Considerando a presença significante de igrejas evangélicas na cidade e um número relativo de evangélicos, é assertiva a ideia de que as imagens, para os católicos, são marcadores identitários que sustentam suas pertenças religiosas e que também funcionam para inserir publicamente a suposta força que o catolicismo ainda goza na cidade, quando levamos em conta que em Borá todos moradores residentes se conhecem. Ainda que de pouca conversa, sabem onde cada pessoa mora e o que faz, estabelecendo, assim, uma relação de forças entre católicos e evangélicos movimentada por referenciais simbólicos.

Os cálculos no posicionamento das imagens, criativamente desenvolvidos pelos devotos, não seriam, portanto, somente meios alternativos que desviam das imposições institucionais ou do consumo padronizado do espaço. Comportariam em si uma outra atribuição de valores construídas com base no referencial - muitas vezes plural - dos próprios agentes. Formaria, desse modo, um espaço "doméstico-sagrado" que, ao ser acessado por qualquer pessoa, seria confrontado por um referencial religioso indicativo. Se o visitante for evangélico, provavelmente haverá conflitos e tensões no conteúdo implícito da mensagem postada pelo morador.

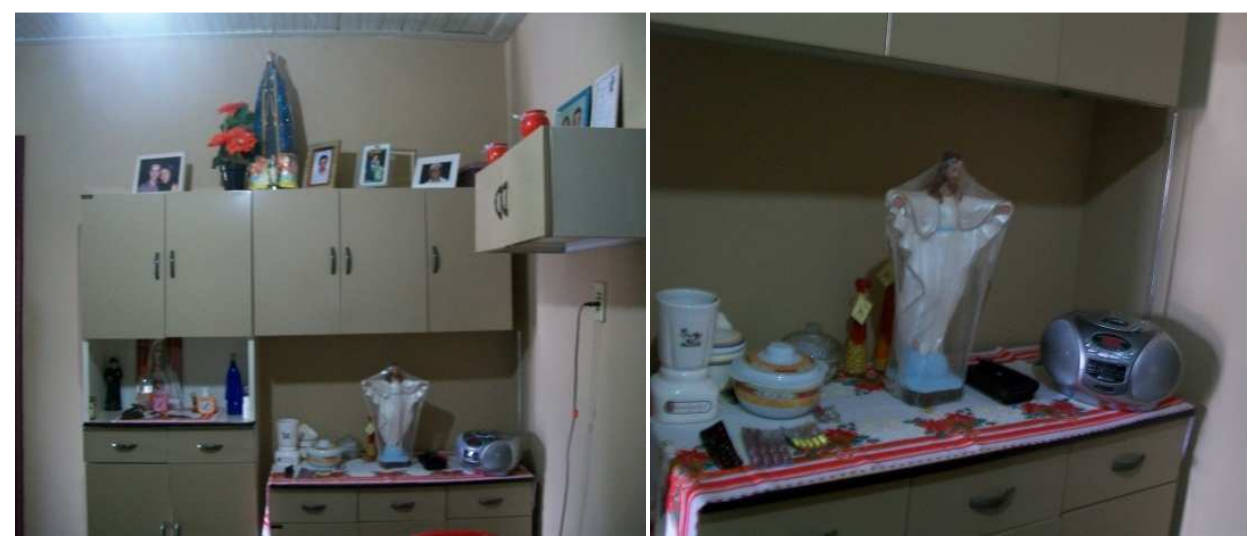

Figura 3

Na figura 3, o cenário que se abre é de uma cozinha; as duas imagens são da mesma residência. $\mathrm{Na}$ parte mais alta do armário, há uma imagem de tamanho grande de Nossa Senhora de Aparecida, retratos de familiares e alguns adereços. 
Na parte esquerda da primeira imagem, está uma imagem de Padre Cícero Romão Batista, uma imagem da Virgem Maria e uma pequena imagem de plástico de Nossa Senhora de Aparecida novamente. No lado direito - tanto na primeira imagem quanto, com um foco maior, na segunda -, há uma imagem de Jesus Cristo, um rádio portátil, algumas louças, outros adereços sobre uma toalha.

Curiosamente, a imagem de Padre Cícero Romão Batista indica um novo ator no campo religioso brasileiro figurando entre santos há muito reconhecidos pela Igreja Católica (SANCHIS, 2007). Cabe aqui pontuar que a senhora dona da casa e seu marido são migrantes pernambucanos, dado que evoca a ideia da presença migratória na cidade de Borá, pois, em outra residência visitada, uma senhora, também migrante, só que cearense, disse-nos que "os santos estavam todos guardados numa caixa" e contou que também era devota de Padre Cícero.

Nessa discussão, sem nos alongarmos nela, é importante compreender a devoção a um santo com base nas atribuições daqueles que conferem tal classificação (BRAGA, 2008, p. 388). O caso de Padre Cícero e do uso de sua imagem no ambiente doméstico nos permite entrever as peculiaridades do catolicismo brasileiro, pois, um santo que não é reconhecido pela Igreja Católica e que tem sua produção imagética em constante uso pelos devotos teria por sinal indícios de ações combinatórias que corresponde às necessidades, crenças, rituais e outros mais sentidos diversos que possibilitam a devoção em meio a canonização e não canonização.

Os posicionamentos das imagens na cozinha revelam algumas estratégias de relação com o sagrado. Quando fizemos a abordagem, a senhora estava limpando seu quintal, numa tarde de sábado, "terminando os serviços de casa para à noite ir à santa missa", como nos relatou. Sua fala mostra-nos uma preocupação em manter tudo ajeitado em casa para depois realizar suas devoções, mas, além disso, indica uma mulher que tem diversos afazeres diários e que, provavelmente, passa boa parte do seu dia na cozinha cumprindo essas atividades.

Consideramos estratégica a colocação dos santos na cozinha pelo contato maior que poderá ter com eles. Essa análise pauta-se na observação de que na sua sala não havia imagens de santos como costumamos encontrar na casa de diversos religiosos. Então, podemos entender que sua organização pessoal, do tempo, dos afazeres diários, está ligada ao contato visual constante com as imagens. Ao mesmo 
tempo em que trabalha na cozinha pode visualizar os mediadores que a conectam ao sagrado.
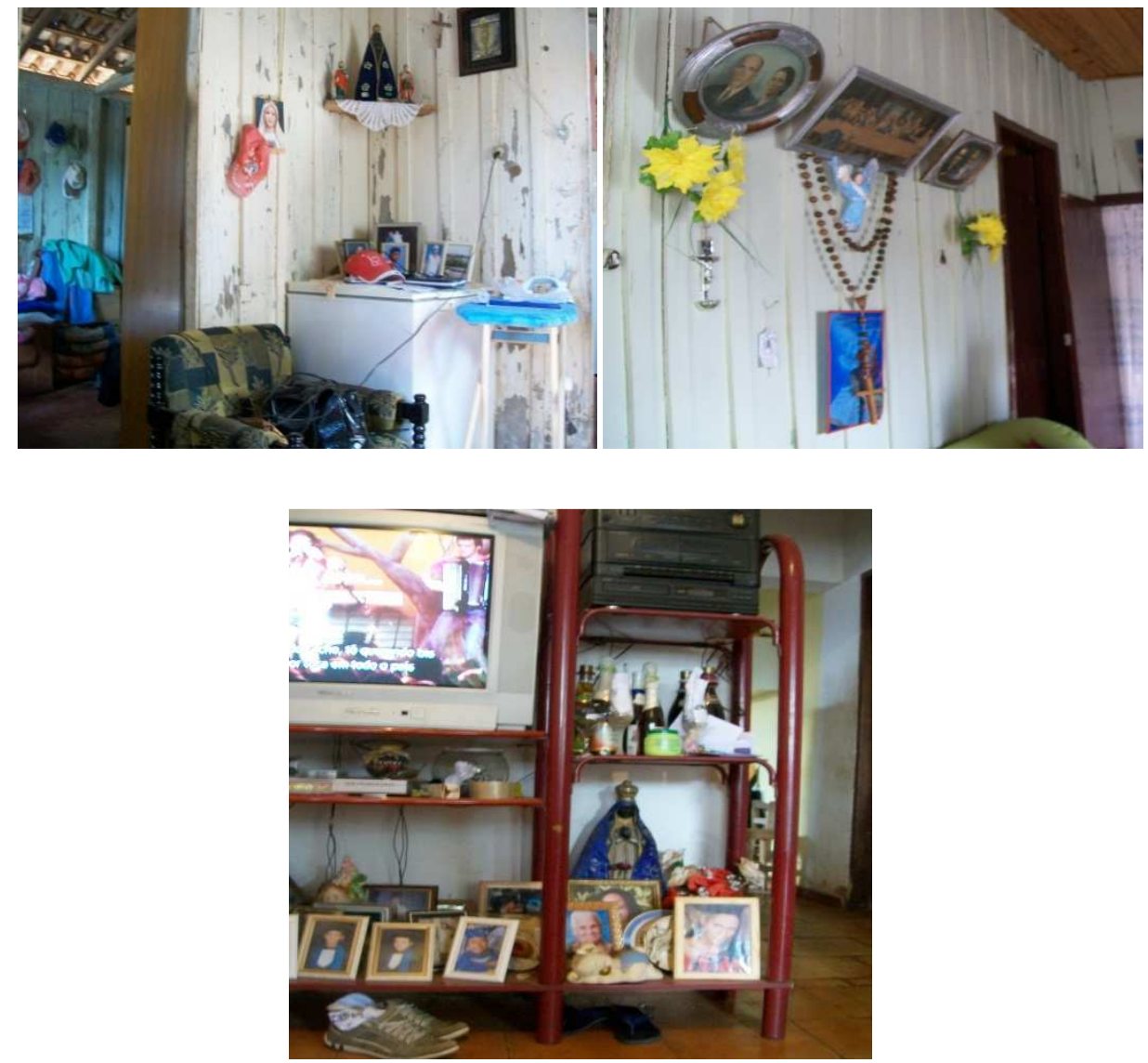

Figura 4

Nesta última parte, buscamos expor, na figura 4, fotografias que demonstram a disposição das imagens de santos na sala das residências. As três fotografias possuem um elemento em comum: imagens de santos estão próximas a fotografias de familiares ou amigos.

Na primeira fotografia, posicionada no canto superior da parede está uma imagem de Nossa Senhora de Aparecida. É possível ver dois outros santos - um em cada lado da imagem -, um crucifixo, um quadro com Jesus Crucificado à esquerda da imagem da santa, e, no canto direito, um quadro da Virgem Maria. As imagens estão posicionadas em torno de um pequeno freezer, onde estão sobrepostas fotografias de ente queridos e familiares.

Na segunda fotografia encontramos na parede os seguintes objetos: no centro um quadro que representa a Santa Ceia, suspendendo um crucifixo de madeira 
de herança portuguesa7, que por sua vez envolve a imagem de um anjo. Ao redor do quadro, dos dois lados, fotografias dos avós paternos e maternos ornados por ramos de flores artificiais. No lado direito ainda se encontra um crucifixo de metal.

A última fotografia mostra uma imagem em tamanho grande de Nossa Senhora de Aparecida envolvida por diversos objetos. Buscaremos descrevê-los tomando por base a imagem da santa: na parte inferior há um ornamento de flores artificiais em seu entorno, diversas fotografias de familiares e entes queridos que se estende por todo o rack; em cima da imagem vemos garrafas de bebidas alcoólicas, um aparelho de som e, no centro, uma televisão que exibe, no momento da conversa, um show de música sertaneja.

Os usos das imagens de santos na sala das residências correspondem àquilo que Durkheim (2008, p. 45) chamou de "representações coletivas", como categorias de pensamento desenvolvidas na esteira do tempo por diversas junções de costumes que foram elaborados combinatoriamente pela sociedade para cumprir determinadas necessidades.

Podemos compreender sua ideia de representações coletivas como sendo "modos de pensar", transmitidos por uma memória social. Do mesmo modo como descreve Geertz (2001, p. 30) que pensamento é igual à conduta, por isso, o pensamento sobre algo é exposto na sua ação expressando sentimentos e emoções com relação ao mundo que o cerca.

Assim, com relação às imagens de santos estarem postas próximas a fotografias de familiares e entes queridos, tal fato pode ser explicado pela ideia de que por meio do contato serão transmitidos proteção, cuidado, saúde, paz, bem estar e toda sorte de graça. Por ocorrerem em diversas casas, compreendemos que essa é uma ideia comum, evidenciando a presença do social na opção individual de escolha do alojamento das imagens.

A relação que também se estabelece no posicionamento das imagens de santos em lugares inusitados - ou em lugares que temos como impróprios para serem depositados, como na terceira fotografia, onde a imagem de Nossa Senhora

\footnotetext{
7 A dona da residência é descendente direta de portugueses que colonizaram a região. Segundo seu depoimento, ela chegou à localidade que hoje é a cidade de Borá ainda criança, o que permitiu a ela acompanhar aos poucos o seu desenvolvimento.
} 
figura entre bebidas alcoólicas e demais ornamentos - insere uma construção do sagrado desenvolvida no dia a dia pelos devotos.

Com isso, não só a imagem do santo é interpretada como sagrada, mas o que o rodeia e convive com seu ícone diariamente também compartilha desse status. Por certo, a observação de Steil (1996) sobre os ex-votos e demais objetos depositados pelos romeiros em Bom Jesus da Lapa, na qual aponta que os objetos do cotidiano se tornam sagrados quando aparecem fora de seu lugar esperado (STEIL, 1996, p. 53), também vale para o interior da casa dos religiosos, que adaptam espaços, e adaptam as imagens de santos aos espaços, para desenvolverem uma relação íntima com o sagrado.

\section{Considerações finais}

Ao analisar as disposições das imagens de santos nas residências, encontramos vários elementos que revelam questões que envolvem opções estratégicas de acomodação dos santos. São, por certo, em todos os casos, lógicas singulares que ressignificam a relação santo-devoto a todo o momento; são aparentemente banais ou simplesmente desprovidas de sentido, mas são objetos de uma cultura material religiosa que sintetizam o ethos e a visão de mundo de um grupo (GEERTZ, 1989, p. 66-67).

Como nas 12 casas que diagnosticamos a diversidade religiosa, deparamonos com uma família em que apenas um membro é evangélico e todos os outros são católicos e não possuem imagens de santos em casa. Uma estratégia perspicaz para evitar conflitos em razão da iconoclastia protestante. Outra residência forneceu-nos um depoimento em que no seio da família, até então totalmente evangélica, a filha de 13 anos resolveu fazer catequese e filiar-se à única Igreja Católica da cidade. Apesar da hegemonia religiosa familiar, a adolescente encontra meios criativos para praticar suas novas convicções religiosas. Tendo em vista o pensamento de Certeau (2011, p. 87), é em meio à dominação e hegemonia - seja ela de que âmbito for - que a pluralidade e a criatividade se articulam, produzindo efeitos imprevistos. 
De fato, os casos estudados e os demais apenas descritos carecem de uma contínua apuração, de modo que seja possível em nossa pesquisa acompanhar a dinâmica que envolve os moradores da cidade de Borá e seus respectivos cotidianos religiosos. Contudo, os dados e as análises que discorremos neste artigo corroboram a discussão sobre a identidade religiosa e sobre a pluralidade religiosa e, com isso, a atenção que se volta sobre as "guerras santas" e os conflitos presentes na nova configuração religiosa que se apresentam ao debate para os cientistas sociais (CAMURÇA, 2009).

Os exemplos aqui descritos e postos demonstram alternativas para as experiências religiosas: na adequação dos espaços das residências para comportar o "sagrado", nos modos de conceber a relação com as divindades ou nas práticas religiosas. São evidências de que o catolicismo brasileiro possui, sendo plural (TEIXEIRA; MENEZES, 2009), um elemento catalisador, dinamizador, que fornece sentidos para aqueles que se valem de sua simbologia.

Assim, podemos sugerir que também os espaços domésticos compõem o panteão da religiosidade, na medida em que entendemos religião no seu sentido superlativo, como afirma Sanchis (2008, p. 77). Isto é, em seu sentido mais abrangente, não como parte da cultura, mas religião como cultura, que fornece orientação, conteúdo e forma para o religioso se guiar no mundo e organizar seu espaço de acordo com os elementos que a cultura põe à sua disposição.

\section{Referências}

BAUDRILLARD, J. (1973). "O sistema funcional ou o discurso objetivo". In: . O sistema dos objetos. São Paulo, Perspectiva.

Boudieu, P. (1998). "Gênese e estrutura do campo religioso". In: A economia das trocas simbólicas. 5. ed. São Paulo, Perspectiva, p. 27-78.

BragA, A. M. C. (2008). Padre Cícero: sociologia de um padre, antropologia de um santo. Bauru, EDUSC.

CAMURÇA, M. (2009). "Entre sincretismos e guerras santas: dinâmicas e linhas de força do campo religioso brasileiro". Revista da USP, São Paulo, n. 81, p. 173-185, mar/maio. Disponível em: <www.revistasusp.sibi.usp.br/pdf/revusp/n81/ 15. pdf >. Acesso em: 2 out. 2011.

CERTEAU, M. (2011). A invenção do cotidiano: artes de fazer. 17. ed. Petrópolis, Vozes, vol. 1. 
DAMATTA, R. (1985). A casa \& a rua: espaço, cidadania, mulher e morte no Brasil. Rio de Janeiro, Guanabara.

Dupront, A. (1995). A religião católica: possibilidades e perspectivas. São Paulo, Loyola.

Durkheim, E. (2008). As formas elementares de vida religiosa. 3. ed. São Paulo, Paulus.

ELIAS, N. (2011). "Do comportamento no quarto". In: uma história dos costumes. 2. ed. Rio de Janeiro, Zahar, vol. 1.

O processo civilizador:

FONSECA, C. (2004). Família, fofoca e honra: etnografia de relações de gênero e violência em grupos populares. 2. ed. Porto Alegre, Editora da UFRGS.

Freyre, G. (1954). Casa-Grande \& Senzala. 8. ed. Rio de Janeiro, José Olympio, vol. 1.

GEERTZ, C. (1989). A interpretação das culturas. Rio de Janeiro, LTC.

(2001). Nova luz sobre a antropologia. Rio de Janeiro, Jorge Zahar.

Hoornaert, E. (1994). História do cristianismo na América Latina e no Caribe. São Paulo, Paulus. IBGE. (2010). Censo 2010. Disponível em: <www.ibge.gov.br/ cidadesat/topwindow.htm?1>. Acesso em: 25 jan. 2011.

LOPES, J. R. (2003). "Imagens e devoções no catolicismo brasileiro: fundamentos metodológicos e perspectivas de investigação". Rever, n. 3, p. 1-29. Disponível em: <www.iesb.br/sipec/revista>. Acesso em: 18 abr. 2011.

(2010). A imagética da devoção: a iconografia popular como mediação entre a consciência da realidade e o ethos religioso. Porto Alegre, Editora da UFRGS.

MEnEzes, R. C. (2004). A dinâmica do sagrado. Rio de Janeiro, Relume Dumará, Núcleo de Antropologia da Política/UFRJ.

. (2005). "Uma visita ao catolicismo brasileiro contemporâneo: a bênção de Santo Antônio num convento carioca”. Revista da USP, São Paulo, n. 67, nov. Disponível em: <www.revistasusp.sibi.usp.br/scielo.php?\%20script=sci arttext\&pid= S010399892005000300004\&lng=pt\&nrm=iso >. Acesso em: 17 jul. 2011.

MonTES, M. L. (1998). "As figuras do sagrado: entre o público e o privado". In: ScHWARCZ, L. M. (org.). História da vida privada no Brasil - contrastes da intimidade contemporânea. São Paulo, Companhia das Letras, vol. 4.

Morales, L. A. (2002). Vai e vem, vira e volta: as rotas dos soldados da borracha. São Paulo, Annablume; Fortaleza, Secult.

MotT, L. (1997). "Cotidiano e vivência religiosa: entre a capela e o calundu". In: SouZA, L. M. (org.). História da vida privada no Brasil - cotidiano e vida privada na América portuguesa. São Paulo, Companhia das Letras, vol. 1. p. 115-220.

Russo, S. M. T. (2010). “Artefatos da fé”. Projeto História - Patrimônio e cultura material, n. 40, jun., p. 393-422. Disponível em: <http://revistas.pucsp.br/ index.php/revph/article/view/6137>. Acesso em: 12 out. 2011. 
SANCHIS, P. (1995). “O campo religioso pode ser ainda hoje o campo das religiões?". In: HoornaERT, E. (org.). História da igreja na América Latina e no Caribe (19451995). Petrópolis, Vozes/Cehila.

. (2007). "Desponta novo ator no campo religioso brasileiro? O Padre Cícero Romão Batista”. Religião \& Sociedade, 27, n, 2, p. 11-29.

(2008). "Cultura brasileira e religião... Passado e Atualidade..." Cadernos CE$R U$, [s.l], vol. 19, n. 2, série 2, p. 71-92, dez.

SANTOS, M. H. S. (2006). O espaço de rezar: a religião católica doméstica na casa rural do Recôncavo Baiano (séculos XVI a XIX). Dissertação (Mestrado em Conservação e Restauro) - PPG-AU, Universidade Federal da Bahia, Salvador.

STEIL, C. A. (1996). O sertão das romarias: um estudo antropológico sobre o santuário de Bom Jesus da Lapa, Bahia. Petrópolis, Vozes.

. (2001). "Pluralismo, modernidade e tradição: transformações do campo religioso". Ciencias Sociales y Religión/Ciências Sociais e Religião, Porto Alegre, ano 3, n. 3, p. 115-129, out.

TEIXEIRA, F. (2005). "Faces do catolicismo brasileiro contemporâneo". Revista da USP, São Paulo, n. 67, nov. Disponível em: <www.revistasusp.sibi.usp.br/scielo. php? script=sci arttext\&pid=S010399892005000300003\&lng=pt\&nrm=iso $>$. Acesso em: 15 jul. 2011.

TEIXEIRA, F.; Menezes, R. (orgs.). (2009). Catolicismo plural: dinâmicas contemporâneas. Petrópolis, Vozes.

Recebido em setembro/2011

Aprovado em março/2012 